\title{
IDEALISMO E FALIBILIDADE NA CONCEPÇÃO DA DEMOCRACIA
}

\section{IDEALISM AND FALLIBILITY IN DEMOCRACY CONCEPTION}

\section{Emerson Ademir Borges de Oliveira ${ }^{1}$}

Resumo: Por muito tempo, a democracia foi erigida a um modelo de “ídolo”, um regime perfeito que deveria ser seguido pelos modelos reais. O trabalho de Nietzsche, nessa seara, rompeu com a ideia dos ídolos, dentre eles a democracia, identificando como químera a crença em tais tradições ou modelos perfeitos. Embora seu trabalho tenha sido de excelente grado nesse tocante, é certo que Nietzsche é um desconstrutivista. Por essa razão, cabe-nos analisar a questão da idolatria democrática e, com base na genealogia nietzscheana, tentar construir um “modelo” realizável de democracia. Nas atuais circunstâncias institucionais, a identificação de um modelo de democracia que apresenta graves falhas e ranhuras é imprescindível para saber até que ponto se busca atingir um modelo democrático, ou se a busca, na verdade, representa uma ilusão vivenciada em pleno seio da democracia. Na verdade, a crise institucional brasileira se deve em grande parte às frustrações decorrentes de se perquirir um modelo inalcançável e desafinado com a realidade democrática nacional. E é justamente na fuga de uma democracia idolatra que se mostra pleno o caminho para superação dos fundamentos das insatisfações populares, realçando-se com mais profundidade os aspectos peculiares da democracia em processo brasileira.

Palavras-chave: Democracia. Reconstrução. Idealismo. Falibilidade.

Abstract: For a long time, democracy was built into an "idol" model, a perfect regimen that should be followed by the real models. Nietzche's work, in that field, broke through the idol concept, among them, democracy, seeing like chimera the belief in such traditions or perfect models. Although his work has been from excelent taste in this particular issue, it's certain that Nietzsche exercises a deconstruction method. That's why it's up to us to analyze the democratic idolatry issue and, based on Nietzsch's genealogy, try to built an achivable democracy "model". In the current institutional circumstances. The identification of a model 
of democracy that has serious flaws and grooves is essential to know to what extent it seeks to achieve a democratic model, our if the ssek, as a matter of fact, represents an illusion experienced in deep core of democracy. Actually, the institutional brazillian crises is being caused by the frustrations arising from assert an unattainable and discord model with the national democratic reality. And it's precisely in the escape from an idolater democracy that the full path to overcoming the fundamentals of popular dissatisfaction shows itself, deeply highlightining the peculiar aspects of the processing brazillian democracy.

Keywords: Democracy. Reconstruction. Idealism. Fallibility.

\title{
1. INTRODUÇÃO
}

Em face das diversas configurações do modelo democrático e da sua natural instabilidade, e admitindo-se que a democracia tangencie por um modelo muito longe do ideal, o que se questiona é que fazer com um modelo imperfeito? Se o modelo ideal serviu apenas à ilusão do povo, servirá um modelo que se assume justamente o oposto?

O objetivo central desse trabalho é justamente demonstrar que é melhor praticar a democracia imperfeita, ainda que como suposto modelo, do que se espelhar em um ideal inexistente. O ídolo - como critica Nietzsche (s.d., p.16), e que serviu de embasamento para nossa teoria - apenas serve para subsidiar uma busca insistentemente inútil:

\begin{abstract}
A última coisa que eu pretenderia seria "melhorar" a humanidade. Não estabeleço ídolos novos; os antigos vão aprender o que significa ter pés de barro. Derrubar ídolos (“ídolos” é o termo que uso para designar "ideais”) - isso sim faz parte de meu ofício. A realidade foi despojada de seu valor, de seu sentido, de sua veracidade à medida que se fingiu mentirosamente um mundo ideal... $\mathrm{O}$ "verdadeiro mundo" e o "mundo aparente" - dito com clareza: o mundo inventado pela mentira e a realidade... Até agora a mentira do ideal constituiu a maldição contra a realidade; a própria humanidade se tornou mentirosa e falsa até em seus instintos mais profundos - até chegar a adorar os valores opostos daqueles que unicamente teriam garantido o florescimento, o futuro, o elevado direito ao futuro.
\end{abstract}

Nesse caminho, surgiu como desafio demonstrar que apostar na democracia enquanto ideal apenas pode servir de engodo ao povo, muitas vezes convencido de que a minoria do poder busca uma democracia sem perceber que ela já existe. 
governo do que depreciar a definição de democracia enquanto processo através do argumento de que a mesma é "formalista”, levar o povo a acreditar que seu desejo será satisfeito se o governo agir em seu interesse e que, insataurado um governo para o povo, se terá alcançado a tão almejada democracia (KELSEN, 1993, p.145).

Até por isso a exploração dos elementos democráticos - como a igualdade, a liberdade e a autodeterminação do povo - pelo método desconstrutivo, de forma a enfatizar que diante de tais caracteres, em maior ou menor grau, é possível se dizer que vivemos em um regime democrático, ou em uma poliarquia, como diria Robert Dahl.

Daí porque, como se verá adiante, urge a inversão da lógica idolatra como sugestão solucional para a presente questão.

Isto é, crer na democracia como um “modelo” cambiante, instável e falho, mas que é “perfeito” nesse exato jeito de ser. Isso desmistifica a democracia como um ente inatingível e passa a visualizar a democracia presente em cada local a cada tempo.

O fato da maioria não governar a minoria não é suficiente para acreditar na inexistência de uma democracia concreta. Tampouco, que o poder deixa de ser do povo se o exerce por meio de representantes, embora não se deva olvidar que isso não significa que os representantes exerçam a vontade dos representados (FERREIRA FILHO, 2001, p.24-25)².

Abordando o caráter democrático da lei, é interessante ter em mente que aqueles que instituem uma ordem política e jurídica de cunho democrático não estão acima da mesma lei que usaram para institui-las. Hodiernamente, entre nós, a referência fica à nossa própria Constituição de 1988. Como ressalta Robert Dahl (2012, p.169), tal ideia tem origem num princípio de justiça segundo o qual as leis não podem ser impostas por algumas pessoas a outras se aquelas não estão igualmente obrigadas a obedecê-las.

Esse é um ponto de partida essencial para se compreender a falibilidade do processo democrático, eis que as leis raramente são puramente guiadas pelo interesse geral. Nenhuma inocência deve haver sobre o fato de que os representantes políticos comumente filtram o conteúdo das leis para atender ou aos próprios interesses ou a grupos de pressão que possuem a capacidade de influenciar os agentes políticos.

Logo, a própria instituição da democracia em um regime de Estado parte do pressuposto de que a Constituição não é feita totalmente à vontade de seu povo, ainda que tal

\footnotetext{
${ }^{2}$ Ainda: "Se o representante fosse um mero porta-voz do povo, ou de seus eleitores, um comissário do povo como antigamente se dizia, ainda haveria algum fundamento para a tese básica desse modelo. Entretanto, os princípios que regem o mandato representativo excluem cabalmente a vinculação do representante a instruções ou mesmo a diretrizes fixadas pelo eleitorado. Mesmo a sua vinculação ao partido por que se elegeu, ou aos princípios constantes do programa deste, se foi tentada na Tchecoslováquia do entre-duas-guerras e no Brasil do período militar, foi abandonada” (FERREIRA FILHO, 2001, p. 25).
} 
vontade fosse una - e bem sabemos que está muito longe de o ser. Mas é necessário que esta mesma ordem seja instituída por aqueles que se submetem a ela, pois, fosse por outrem, violada estaria a autodeterminação do povo, corolário da democracia.

Mas a autodeterminação não significa que a ordem jurídica combina exatamente com o anseio popular, mas sim que é proposta com a intenção de, ao menos em parte, atender, cambaleante, a vontade que uma minoria representante transmite como sendo da maioria.

E, nessa edificação, essa vontade democrática é tornada lei fundamental, submetendo a todos. E não há qualquer contradição em termos que a democracia assim se instaure. Mas é provável que houvesse se a democracia fosse vista como ideal.

Essas são apenas algumas divagações que norteiam as conclusões a serem atingidas por este trabalho. A seguir, buscaremos aprofundar tais discussões.

\section{A INVERSÃO DA LÓGICA IDOLATRA}

Não se negue que o objetivo de todo projeto democrático deva ser a busca por uma ou outra orientação de governo. No entanto, partindo de Spinoza, Manoel Gonçalves Ferreira Filho (2001, p.25) lembra que no político domina mais o sentimentalismo do que a razão. Orientação de governo é, no mais das vezes, uma infundada tentativa de racionalizar o discurso eleitoral, mormente criada pela mídia, para subtrair a verdadeira essência da disputa política ${ }^{3}$.

Eis a razão pela qual a esmagadora maioria dos partidos que alcançam o poder preferem vertentes ideológicas mais centrais, sem o enfrentamento decisivo de temas complexos ou polêmicos. Preferem a opção “sobre o muro”, típica daqueles que manuseiam a manutenção do controle do poder. Apenas.

Veja-se, a este propósito, o desvio que a política tem proporcionado ao Judiciário na inação do Legislativo, como, por exemplo, o julgamento da Arguição de Descumprimento de Preceito Fundamental 54, acerca do aborto de anencéfalos, temática em que os criadores da lei se mostraram sempre recalcitrantes. Até mesmo o Executivo prefere posições mais tradicionalistas sobre o tema, sobretudo de influência religiosa.

Não que tal inação seja a única razão da politização do Judiciário - e sobre o tema já expusemos com maior cuidado em nossa dissertação (BORGES DE OLIVEIRA, 2013) -, mas

\footnotetext{
${ }^{3}$ Em continuidade: "Ademais, os programas, seja dos partidos, seja dos candidatos, são sempre vagos, imprecisos, porque visam a aliciar o maior número, procurando chocar o mínimo possível” (FERREIRA FILHO, 2001, p.25).
} 
não se deve ignorar que a falta de coragem para o enfrentamento de questões sensíveis é também uma das razões que as desvia para o Judiciário.

A propósito, no julgamento da citada ADPF, o Ministro Ricardo Lewandowski reverberou em seu voto:

\footnotetext{
Destarte, não é lícito ao mais alto órgão judicante do País, a pretexto de empreender interpretação conforme a Constituição, envergar as vestes de legislador positivo, criando normas legais, ex novo, mediante decisão pretoriana. Em outros termos, não é dado aos integrantes do Poder Judiciário, que carecem da unção legitimadora do voto popular, promover inovações no ordenamento normativo como se parlamentares eleitos fossem.
}

Mas, ao contrário do que se possa pretender afirmar, este não é um desvio do poder político democrático. Ao contrário, a ele é inerente. É inerente que num flanco aberto de oposição, com "bilhetes de retorno", e sem garantia alguma de perpetuação no poder, o político tente ao máximo se valer da mais-valia de decidir, em caráter animoso, apenas o óbvio, se não quiser ser relegado a segundo plano no próximo pleito.

Isso quer dizer que a oposição na política acaba perfazendo um jogo de disputa proporcional ao risco. Apenas ataca com mais gravidade ou toma posições menos ortodoxas aquele que está alijado, ao menos temporariamente, da disputa do poder. Mesmo a oposição ao governo que se encontra em reais condições de alcançá-lo prefere ser mais tradicionalista.

Por outra via, se aquele que se encontra mais marginalizado obter sucesso na disputa política - não apenas em nível Executivo, mas principalmente Legislativo, que tem a característica de ser muito mais plural -, deixa de atuar de forma heterodoxa e trocará tais posicionamentos por métodos mais tradicionais, no intuito de não perder o status obtido.

Essa classe dirigente que efetivamente governa - como já prelecionara Gaetano Mosca em seu Elementi di scienza politica, de 1896 -, em vista do fato de que as decisões fundamentais são impossíveis de serem tomadas por todos e razoável que não seja por apenas um, pode estar ou não aberta aos ecos da maioria que os escolhe (FERREIRA FILHO, 1974, p.22-23).

O problema é que a poluição eleitoral nasceu junto com a política e com a sociedade. E todos os esforços, como aqueles tratados por nós no último tópico do capítulo precedente, têm o condão tão somente de amenizar tais impactos. A poluição existe para eleger, para manter e para dirigir. Não há eleições em que o povo não esteja sendo, minimamente, vítima de algum engodo. Assim como não há decisão que seja puramente neutra e alheia a quaisquer impactos, salvo uma construção racional. 
Discorremos, à guisa de exemplo, sobre a razoável posição do Ministro Gilmar Mendes no julgamento dos RO 801 e no AgRgAg 5.282, pelo Supremo Tribunal Federal, no sentido de que a publicação e a prestação de informação sobre os atos municipais não tem o condão de proporcionar propaganda ilegal. E não discordamos desse posicionamento.

Mas não se pode ignorar que, como lembrou o próprio Ministro, aquele que detém o poder e busca a reeleição tem em suas mãos a “mais-valia” política da máquina institucional. E isso certamente corresponde a uma espécie de poluição do processo eleitoral. Ainda mais nos tempos atuais em que a publicidade dos atos pode decorrer de formas múltiplas e de rápida disseminação.

Assim, é inegável que a publicidade e a transparência que são exigidas do agente político andam lado a lado com a propaganda política do candidato.

Daí porque o esforço de Schumpeter (1947, p.253) em seu Capitalism, socialism and democracy em apontar os fatores irracionais que permeiam o ambiente eleitoral, apontando a falta de realidade da doutrina clássica da democracia.

But though a common will or public opinion of some sort may still be said to emerge from the infinitely complex jumble of individual and group-wise situations, volitions, influences, actions and reactions of the "democratic process", the result lacks not only rational unity but also rational sanction. The former means that, though from the standpoint of analysis, the democratic process is not simply chaotic - for the analyst nothing is chaotic that can be brought within the reach of explanatory principles - yes the results would not, except by chance, be a meaningful in themselves - as for instance the realization of any definite end or ideal would be. The latter means, since that will is no longer congruent with any "good", that in order to claim ethical dignity for the result it will now be necessary to fall back upon an unqualified confidence in democratic forms of government as such - a belief that in principle would have to be independent of the desirability of results. As we have seen, it is not easy to pleace oneself on that standpoint. But even if we do so, the dropping of the utilitarian common good still leaves us with plenty of difficulties on our hands ${ }^{4}$.

\footnotetext{
${ }^{4}$ No vernáculo: “Mas, apesar da vontade comum ou de algum tipo de opinião pública, deve ser dito, para fugir da infinita confusão de complexas relações, situações, volições, influências, ações e reações individuais ou coletivas no processo democrático, o resultado não depende exclusivamente do aspecto racional, mas também da sanção racional. A primeira significa que, embora do ponto de vista analisado, o processo democrático não é simplesmente caótico - para o analista, nada é tão caótico que possa ser trazido ao alcance de princípios explicativos -, mas sim os resultados que não, salvo por acaso, possuem um significado em si mesmos - como, por exemplo, a realização de qualquer fim definido ou ideal seria. O segundo significa que, desde que a vontade não seja mais congruente com um "bem”, que, a fim de reivindicar a dignidade ética para o resultado, agora, é necessário retomar uma confiança sem reservas em formas democráticas de governo como tal - a crença de que, em princípio, teria de ser independente do desejo de resultados. Como vimos, não é fácil localizar-se nessa perspectiva. Mas mesmo se o fizermos, o abandona do bem comum utilitarista aind nos deixa com muitas dificuldades em nossas mãos”.
} 
Além disso, uma outra decorrência do regime democrático é o fato de que a classe dominante não pretende ser excluída do processo tão cedo e, para tanto, “chuta a escada”, impedindo ao máximo a ascensão daqueles que almejam o poder.

Como relembra Manoel Gonçalves Ferreira Filho (1974, p. 24-25), em lição de Mosca, essa elite governante acaba constituindo uma espécie de classe social definida politicamente:

Provêm, não raro, das mesmas famílias, que já houve quem procurasse catalogar, gozam da mesma condição de vida, tiveram a mesma educação, partilham da mesma cosmovisão, dos mesmos valores, sofrem das mesmas preocupações, frequentam o mesmo círculo, mutuamente se reconhecem, e pelo povo são reconhecidos, como membros de uma só categoria social.

Igualmente, essa elite tende a se tornar estável, ocupando os filhos o lugar dos pais. Para essa estabilidade contribui, menos, a hereditariedade, mais, a herança. Sem dúvida, para ela contribui a constância, nos descendentes que se mantêm na elite, de traços individuais que permitiram aos ascendentes preponderar no seu setor de atividade. Essa constância, entretanto, não parece ser a regra.

Para a estabilização de uma elite, representa papel fundamental a herança, tanto de posição quanto de riqueza. Os filhos dos membros da elite costumam permanecer nessa elite, ainda que não tenham, ou tenham em nível muito atenuado, as qualidades que levaram seus pais a preponderar em suas atividades e assim aceder à elite. Isso é auxiliado, sobremaneira, pela qualidade da formação que recebem, nas melhores escolas, dos melhores professores, com maiores recursos. É facilitado pela ação dos apadrinhamentos, do nepotismo. É particularmente propiciado pela fortuna, em geral amealhada pelas elites. Por isso é que toda elite "tende a se tornar hereditária, de fato se não de direito”, como, a propósito da União Soviética, expôs MILOJAN DJILAS.

É claro que não se deve olvidar, novamente conforme Manoel Gonçalves Ferreira Filho (1974, p. 25), que existe mobilidade e trânsito entre a elite e a massa. E, na realidade, a intensidade desse trânsito pode oferecer um excelente indicador do grau democrático de um país. Entre nós, tivemos a oportunidade de visualizar um partido de base operária ascender ao mais alto grau do Executivo nacional, embora muito se discuta sobre a manutenção dessa mesma raiz ao longo de seu desenvolvimento.

Mas é fato que, ainda sim, a classe dominante marca papel fundamental na história política do país.

Recentemente, o ex-presidente José Sarney anunciou que não mais se candidataria a cargos públicos. Sua história política, no entanto, remonta ao ano de 1955, quando assumiu suplência de deputado federal. Com 59 anos de carreira política - a mais longa do Brasil - e 36 anos de senado - superando Ruy Barbosa com 31 -, Sarney atuou sob quatro Constituições (1946, 1967, 1969 e 1988) e quinze Presidentes diferentes. Além de deputado federal, foi governador do Maranhão, Senador pelo Maranhão e Amapá e presidente da República. 
Mas, para os fins que aqui interessam, deixou marcada sua hereditariedade política. O filho Zequinha Sarney foi eleito deputado estadual em 1978 e deputado federal por sete mandatos consecutivos. Roseana Sarney, a filha, foi deputada federal e governadora do Maranhão por quatro mandatos, chegando a ser pré-candidata à Presidência da República, pelo PFL, em 2001. Apenas o filho Fernando Sarney não veio a ocupar cargo público, embora se apresente nos bastidores da política.

Vários exemplos poderiam ser dados em terras tupiniquins acerca das chamadas “oligarquias políticas”, a demonstrar que, ainda hoje, há papel preponderante da classe dirigente na sua perpetuação hereditária. Cite-se a esse propósito a corrida presidencial de 2014, em que figuraram entre os três principais candidatos Aécio Neves, neto de Tancredo Neves, que exerceu sua carreira política ao longo de cinquenta anos, e Eduardo Campos falecido pouco menos de dois meses das eleições -, neto de Miguel Arraes, três vezes governador de Pernambuco.

O maior problema, diante de tais dados, é que não se vislumbra uma substituição da classe dirigente pela massa de forma imediata. Como ressalta Manoel Gonçalves Ferreira Filho (1974, p. 23), “derrubada que seja uma elite dirigente por um movimento de massa, a desorganização e o esboroamento da estrutura social e política só serão evitados se da massa surgir uma minoria capaz de substituir a antiga autoridade, tomando o seu lugar e assumindo suas funções”.

Por isso, Manoel Gonçalves Ferreira Filho (2001, p. 29) defende como elemento da democracia “um certo ‘pessoal’ (personnel) político”, isto é, a existência de um corpo de pessoas "aberto à ascensão dos que sejam capazes, embora nascidos nas classes mais modestas”.

Para se ter uma ideia da discussão que essa vertente provoca, Robert Dahl, nos anos 60, envolveu-se em uma polêmica intelectual com Wright Mills acerca da natureza política dos Estados Unidos. Mais reacionário, Mills afirmava que os Estados Unidos eram controlados por uma elite unitária e restrita. Já Dahl afirmava que, na realidade, existiam várias elites diferentes, contrabalanceando-se em situações de conflito e de união. Esta, aliás, constitui uma identificação mais clara do processo democrático brasileiro.

Dentre um dos critérios que Dahl (2012, p.171) elege como necessários para a configuração de um regime democrático, indica a participação efetiva. Define: 
resultado final. Devem ter oportunidades adequadas e iguais de colocar questões na agenda e de expressar seus motivos para endossar um resultado e não outro.

E, vinculado a esse, sugere um quarto critério: $O$ demos deve ter a oportunidade exclusiva de decidir como as questões serão colocadas na agenda de assuntos a serem decididos mediante o processo democrático (DAHL, 2012, p. 179).

Ocorre que, com raras exceções, o que se assiste na prática é o esgotamento da participação do cidadão no momento de escolha do candidato, havendo baixíssimo entroncamento popular no exercício do mandato. A classe dirigente, na realidade, prefere deixar o povo fora da participação desse processo. Acaba sendo uma luta, da classe mais fraca, ante a maré. Urge aí a necessidade do apelo popular pelos ainda alijados políticos para que sua ascensão permita a efetivação de promessas eleitoreiras.

Mesmo instrumentos nacionais que poderiam auxiliar tal participação ou são esquecidos ou são desvirtuados. Cite-se, por exemplo, a ausência de instalação do Conselho de Responsabilidade Fiscal, nos termos do artigo 67 da Lei Complementar 101/2000, que convoca "entidades técnicas representativas da sociedade" para o "acompanhamento e avaliação, de forma permanente, da política e da operacionalidade da gestão fiscal”, visando, entre outras medidas, maior eficiência nos gastos públicos, na arrecadação de receitas, transparência da gestão fiscal, padronização de prestação de contas, estudos e diagnósticos fiscais etc.

A grande questão é que nada disso deve ser considerado como desvirtuamento da democracia.

Partir da concepção de Dahl, como ressalta Manoel Gonçalves Ferreira Filho (2001, p. 25), de que a democracia constitui modelo ideal inatingível e que, na realidade, o que se tem são poliarquias é, também, uma maneira indireta de se afastar de qualquer populismo democrático.

Mas Dahl (s.d., p. 26), ainda sim, identifica a democracia como modelo idealizado, condição que não reputamos válida, eis que inexistente qualquer regime que se eleja ídolo. Colocar a democracia em um pedestal irreal e inatingível é muito pouco e insuficiente para compreender que os modelos poliárquicos são o bastante.

Dahl não está, todavia, errado. Apenas parte de uma concepção que rejeitamos neste trabalho: a de que existe um modelo de democracia de nível perfeito. Aquilo que não pode ser alcançado por estar acima da realidade não merece ser taxado de perfeito, até porque tal termo é completamente impreciso e nada explica. Não caberia a nós humanos que construímos 
democracias reais - e completamente imperfeitas - conseguir determinar o que é, afinal, perfeito, ainda que reconheçamos ser inatingível.

Como ressalta Dahl (2012, p. 171), um processo democrático e um governo democrático "talvez" nunca venha a existir na realidade - preferiríamos excluir a expressão "talvez”. E os critérios que usa para a averiguação de um regime democrático "representam ideias de possibilidades humanas com as quais a realidade pode ser comparada”.

O eterno professor de Yale, falecido este ano, reconhece que, apesar da sua teoria do processo democrático e dos elementos que aponta, na prática ela é "radicalmente incompleta" e inexiste "uma solução definitiva para a maioria” dos problemas que envolvem a democracia (DAHL, 2012, p. 182) ${ }^{5}$.

Nessa toada, Dahl aponta nove problemas teóricos que merecem profunda reflexão:

a) O conceito de povo para a democracia, isto é, o demos, jamais incluirá todos aqueles sujeitos às leis. Mesmo em países de sufrágio universal, há limites traçados para a participação popular. Entre nós, por exemplo, por força do artigo 14 , $\S \S 1^{\circ}$ e $2^{\circ}$, CF, não podem votar os menores de dezesseis anos, os estrangeiros e os conscritos, durante o período militar obrigatório. Em muitos lugares, as mulheres apenas conquistaram o direito de votar em meados do século XX. Logo, nenhum juízo geral é de fato possível (DAHL, 2012, p.183).

b) Não há uma regra decisória segura para as decisões em âmbito democrático. Mesmo o universalmente válido principio da maioria, esbarra em um problema de definição sobre o que seria maioria. O termo acaba servindo “a uma família de regras possíveis”. Como ressalta o cientista político, “todas as regras numéricas (...) estão sujeitas a defeitos em potencial, tais quais os ciclos nos quais nenhuma preferência majoritária pode ser definitivamente estabelecida” (DAHL, 2012, p. 183-184).

c) Há nítidos problemas procedimentais para o alcance do bem público. Para alguns, todavia, deve-se priorizar os “resultados substantivos das decisões”, isto é, o aspecto material, em detrimento do procedimental. Dahl (2012, p.184) identifica como extremamente complexo distinguir o que estaria envolvido em cada aspecto.

d) O termo povo volta à questão no tocante à sua própria definição, mostrando-se como um dos problemas mais insolúveis da democracia. Como definir o que seria um "grupo adequado de pessoas” capaz de governar a si mesmo? Quem poderia estar incluído nessa definição? (DAHL, 2012, p. 184-185).

\footnotetext{
${ }^{5}$ Já quase no final de sua vida, esse tom pessimista ficou mais patente no escrito How democratic is the American Constitution?, em que criticou veementemente os instrumentos democráticos norte-americanos.
} 
e) As ideias democráticas, de maneira geral, acabaram englobadas por tipos radicalmente diversos de sistema político: a cidade-Estado e o Estado nacional. "Será possível, portanto, especificar um conjunto único de instituições necessárias para o processo democrático” (DAHL, 2012, p. 185), isto é, que possa ser aplicado indistintivamente a qualquer Estado?

f) Em face da impossibilidade do alcance de um nível ideal de democracia, qual seria um critério seguro para afirmar, na realidade, que seus requisitos são cumpridos de forma satisfatória ou não? Qual a linha de separação entre o que pode e o que não pode ser considerado democrático? (DAHL, 2012, p.185-186).

g) Uma vez edificada uma determinada poliarquia, haveria a possibilidade da mesma caminhar em direção ao ideal democrático? Para alguns utópicos, sim. Para a contracorrente do pensamento moderno, "tendências poderosas, como uma tendência universal à oligarquia, impõem limites insuperáveis às possibilidades da democratização mais ampla” (DAHL, 2012, p. 186).

h) O desenvolvimento democrático nos Estados nacionais acabou gerando certa competição por ideias e ideais entre indivíduos e grupos capazes de influenciar o poder. Onde fica, nesse entrave, o ideal do bem comum tão arraigado à democracia? (DAHL, 2012, p.186).

i) Por fim, quais são os limites e possibilidades do processo de democratização em face de um mundo cada vez mais dinâmico e globalizado? Os governos ainda não democráticos possuem condições de assim se manterem? E como poderiam ser classificados se ainda supostamente não atingiram um limiar mínimo de poliarquia? Nota-se, mais uma vez, o problema dos limites entre o que pode e o que não pode ser considerado democrático (DAHL, 2012, p.186-187).

A partir destes questionamentos oferecidos por Robert Dahl, a primeira conclusão, pertinente ao objetivo deste trabalho, é a inutilidade/impossibilidade de um regime democrático alcunhado de ideal. É impossível por conta da falta de parâmetros tanto para definir o que seja ideal, como para definir se as demais poliarquias estariam mais próximas ou mais afastadas do mesmo. É inútil porque a democracia que se almeja é aquela real, de acordo com as condições proporcionadas pela população de um determinado Estado e em um determinado tempo, analisando-se várias variantes, como grau de oposição, participação política, nível de igualdade material, liberdade etc, todos estes, igualmente, impossíveis de maior precisão.

O regime democrático como ídolo pode fazer com o que o homem mantenha sempre a cabeça nas nuvens enquanto os pés estão no chão, visualizando um horizonte que não existe 
enquanto a realidade passa ao largo. Seria absolutamente inútil, nos dias atuais, pretender que os governantes brasileiros decidam com base tão somente em um chamado bem comum, se é que isso existe. Toda análise irreal, que busque justificar a democracia por conceitos ideais, acabará escondendo os grandes problemas que se instauram na prática.

\section{RUMOS DEMOCRÁTICOS FORA DO IDEALISMO}

Diante desse quadro, que se assemelha, digamos, negativista, eis que realista, surge a questão: como proceder em relação a um processo democrático naturalmente tão falho? É possível deixar de se guiar por um ideal e assumir uma imperfeição como um modelo, digamos, “ideal”? A resposta para esta pergunta é, nos termos deste trabalho, sim.

Dissemos das dificuldades ensaiadas pelas classes dirigentes para conceder acesso àqueles que se encontram fora do ambiente eleitoral. É natural, ainda, que outros obstáculos acabem se erguendo em face das classes excluídas, como, talvez o maior deles, o aspecto financeiro.

De acordo com dados do Tribunal Superior Eleitoral, a campanha eleitoral no Estado do Espírito Santo, em 2014, considerando-se o governo do Estado, Senado, Câmara dos Deputados e Assembleia Legislativa, pode chegar a custar R\$ 460,35 por eleitor. Considerando apenas o governo capixaba, a corrida custa $\mathrm{R} \$ 11,31$ por eleitor. Em Roraima, este valor é muito mais alto, cerca de R\$ 90,00 por eleitor.

Conforme análise da Revista Época, no tocante às eleições de 2010, em Roraima cada voto para deputado federal custou R\$ 66,16. Dentre os candidatos eleitos, Sandro Mabel (PR-GO) apresentou receitas de R\$ 4,9 milhões, menos do que Wilson Picler (PDT-PR), que ficou de fora, embora tenha arrecadado R \$ 5,6 milhões. O custo por voto mais alto foi de Edio Lopes (PMDB-RR) com a relação custo/benefício de R\$152,14 por eleitor ${ }^{6}$. Em média, a eleição de cada um dos 513 deputados custou R\$ 1,2 milhão.

E, diante da ausência do financiamento público de campanha, são os próprios candidatos que, grosso modo, precisam buscar a arrecadação necessária para os custos da corrida eleitoral. Fica fácil concluir que a grande parte dos cargos eletivos no Brasil,

\footnotetext{
${ }^{6}$ Disponível em: <http://revistaepoca.globo.com/Revista/Epoca/0,EMI257288-18049,00-

QUANTO+CUSTA+SER+DEPUTADO.html>. Acesso 14 ago 2014.
} 
mormente os federais, pairam na mão de pessoas com elevados recursos financeiros ou alta capacidade de captação dos mesmos.

Obstáculos como esse não parecem de simples solução. Nem mesmo se poderia afirmar, rasteiramente, que seriam solucionados pelo financiamento público das campanhas. No mais das vezes, é apenas coletivamente ou, em alguns casos, por ocasião de uma utilização estratégica do voto proporcional ${ }^{7}$, que as classes mais abastadas chegam ao poder. Mesmo em casos de apadrinhamento político, nota-se que existe profunda tendência de conversão do apadrinhado à classe já dominante do padrinho ${ }^{8}$.

Nessa razão, o aparecimento de novas figuras políticas, desvinculadas daquelas que já ocupam cargos públicos, ocorre de maneira progressivamente morosa. Mas ocorre, desmistificando a ideia de um círculo fechado e intransponível. Para que se tenha uma ideia, nas últimas quatro legislaturas, a Câmara dos Deputados apresentou uma renovação média de cerca de $40 \%$ das cadeiras, o que inclui figuras que até então eram totalmente alijadas do círculo político.

Ao depois, a própria democracia tem o dom de provocar mudanças mais sensíveis no quadro político em situações de crise de representatividade. Com uma votação história nas eleições italianas de 2013, o comediante genovês Beppe Grillo e seu MoVimento 5 Estrelas acabaram obtendo 25\% dos votos e garantindo 109 assentos na Câmara dos Deputados.

Assim, a democracia tem a capacidade de se redesenhar quando necessário, conduzindo ao processo democrático mais personagens, capazes de pluralizar o debate.

Nesse diapasão, salutar o trabalho que os partidos menores promovem em relação ao necessário pluralismo político, escorando possíveis novas figuras a serem inseridas no processo democrático.

Já dissemos, noutra oportunidade, analisando julgamento do Supremo Tribunal Federal acerca das cláusulas de barreira à brasileira (ADIs 1351 e 1354), que tornariam praticamente nulas a propaganda partidária e o acesso ao Fundo pelos partidos menores,

\footnotetext{
${ }^{7}$ Nas eleições de 2002, o candidato Enéas Carneiro, do PRONA, obteve 1.573.112 votos para a cadeira de deputado federal por São Paulo. Com uma votação recorde e a frente de um partido pequeno, acabou levando seis cadeiras, sendo que um dos eleitos para a Câmara dos Deputados obteve apenas 275 votos.

8 "Muitos chefes municipais, mesmo quando participam da representação política estadual ou federal, costumam ser tributários de outros, que já galgaram, pelas relações de parentesco ou amizade, pelos dotes pessoais, pelos conchavos ou pelo simples acaso das circunstâncias, a posição de chefes de grupos ou correntes, no caminho da lidenraça estadual ou federal. Mas em todos esses graus da escala política impera, como não podia deixar de ser, o sistema de reciprocidade, e todo o edifício vai assentar na base, que é o 'coronel', fortalecido pelo entendimento que existe entre ele e a situação política dominante em seu Estado, através dos chefes intermediários” (LEAL, 2012, p.63).
} 
colocando em risco seu próprio funcionamento, que não há representavidade democrática se não for atrelada às minorias.

O Ministro Ricardo Lewandowski ressalta que a atabalhoada alteração pode levar ao privilégio dos partidos maiores, em detrimento dos "partidos menores e ideológicos”. É que, como bem temos assistido na realidade partidária brasileira pós-Constituição de 1988, a ideologia partidária mostra-se inversamente proporcional ao tamanho do partido. Assim, quanto menor o partido, maior a representatividade, eis que, embora não puro, estabelece critérios mais nítidos das razões que conduzem ao voto popular. Isto é, o esfacelamento ideológico propugnado pelos interesses escusos de partidos maiores não atingiu ainda os partidos menores, tornando possível visualizar com mais lucidez o perfil da parcela minoritária que busca seus representantes nestes partidos.

Assim é que a restrição aos partidos menores conduz, em última análise, a um rompimento da própria representatividade, na medida em que é justamente nestes partidos que se torna mais clara a própria questão da representação: quem e quais interesses o partido representa? (BORGES DE OLIVEIRA, 2011, p. 30-31).

É evidente que, em termos reais, muitos partidos pequenos podem acabar servindo a legendas de aluguel, mas esse é um risco inerente ao regime democrático. Na balança da proporcionalidade, muito pior à democracia é a extinção dos mesmos, mesmo que por vontade da maioria. Como já ressaltamos, a lição de Carl Schmitt (1971, p. 49) é sempre atual: “quem domina 51\% pode tornar ilegal, legalmente, os 49\% restantes”.

Conforme o relatório do Ministro Marco Aurélio naquela ocasião, com as cláusulas pretendidas a maioria dos partidos nacionais acabariam ficando sem recursos e funcionamento parlamentar $^{9}$.

Ademais, conforme ressalta o supracitado Ministro:

\begin{abstract}
para aqueles preocupados com a proliferação dos partidos políticos, há de levar-se em conta que o enxugamento do rol é automático, presente a vontade do povo, de quem emana o poder. Se o partido político não eleger representante, é óbvio que não se poderá cogitar de funcionamento parlamentar. Considerada a ordem natural das coisas, cuja força é insuplantável, a conveniente representatividade dos partidos políticos no parlamento fica jungida tão somente ao êxito verificado nas urnas, entendendo como tanto haver sido atingido o quociente eleitoral, elegendo candidatos, pouco importando o número destes. Só assim ter-se-á como atendido o fundamento da República, ou seja, o pluralismo político, valendo notar que o verdadeiro equilíbrio decorre do somatório de forças que revelem a visão dos diversos segmentos que perfazem a sociedade. Em síntese, não elegendo candidato, o partido fica automaticamente fora do contexto parlamentar ${ }^{10}$.
\end{abstract}

\footnotetext{
9 “Ainda no tocante à razoabilidade, mostra-se imprópria a existência de partidos políticos com deputados eleitos e sem o desempenho parlamentar cabível, cumprindo ter presente que, a persistirem partidos e parlamentares a ele integrados, haverá, em termos de funcionamento parlamentar, o esvaziamento da atuação das minorias”. Voto do Min. Rel. Marco Aurélio. ADI 1.351.

${ }^{10}$ Voto do Min. Rel. Marco Aurélio. ADI 1.351.
} 
Vale dizer: a democracia acaba se redesenhando automaticamente por ser um regime já impregnado na concepção de Estado do povo brasileiro.

Neste caso em questão, fora o Judiciário que exercera o seu papel contramajoritário e protegeu o regime democrático de ser arranhado pela vontade de uma maioria legislativa.

O tema da cláusula de barreira oferece-se, assim, como um vetor extremamente limitativo de posições ideológicas minoritárias, o que, sem dúvida, compromete a representatividade democrática. Felizmente, em adesão à jurisprudência alemã, o Supremo Tribunal Federal ressaltou que, na medida da razoabilidade e da proporcionalidade, a cláusula, tal como colocada, ofenderia o sistema constitucional eleitoral e representativo brasileiro.

Não que isso impeça qualquer cláusula limitativa, sobretudo as de caráter proporcional, extremamente úteis, como demonstrou a experiência tedesca. O fato é que jamais podem tais cláusulas se tornarem intimidativas da própria vontade popular, afastando os anseios ideológicos dos partidos que refletem essas proposições.

Em nome da erupção de novas ideologias, manifestações minoritárias e candidatos até então excluídos do poder, é essencial que haja vida aos partidos menores, permitindo que, na realidade brasileira, se dê continuidade e aceleração ao processo de substituição de pretensas oligarquias políticas.

Em países de desenvolvimento democrático, a fundação de uma nova democracia é completamente ilusória. O que existe, em verdade, é o desenvolvimento, progressivo, de uma democracia já existente. Apenas por revolução seria possível substituir um regime autocrático por um democrático, e mesmo um democrático por um new democrático.

A ideia de uma participação efetiva, igual e adequada de todos os cidadãos é um engodo. Não há igual oportunidade entre todos os submetidos à uma ordem jurídica de apresentar seus motivos em prol de uma ou outra orientação política. E jamais existirá, seja qual for o grau do modelo poliárquico.

O que não condiz com o regime democrático é a total desconsideração às preferências dos cidadãos, o que não significa que exista igual consideração em relação a todos eles, como pretendia Dahl (2012, p. 172).

Mas a democracia é a arte de buscar minimizar diferenças e uma vertente objetiva pela qual faz isso é a cláusula do voto de igual valor, one man one vote. A ideia, bastante simples por sinal, é um dos maiores baluartes do regime democrático, pois permite que, pelo menos em um dado momento, todos sejam quantativamente iguais (DAHL, 2012, p. 172175). Claro que entra em jogo a influência no processo eleitoral, mas essa é outra questão. 
Ao menos quanto ao valor do voto, todos são iguais. Repisamos, todavia, que, em lugar algum, todos estão submetidos a qualquer sufrágio que se considere de fato universal. Sempre, e no nosso caso por questões até lógicas, alguém estará excluído desse processo. Assim, por exemplo, a Constituição excluiu os menores de 16 anos, o que não significa que pessoas nessa idade não possam ser politicamente instruídas. Mas apenas o constituinte viu por bem estabelecer um limite mínimo razoável e objetivo. Logo, toda exclusão deverá respeitar dois critérios: ser razoável/proporcional e objetiva, sob pena de ser, na realidade, discriminatória e, logo, antidemocrática.

Para as eleições de 2014, o Tribunal Superior Eleitoral irá permitir o voto em trânsito, um pleito antigo e necessário, de forma a viabilizar maior participação popular daqueles que estiverem fora do domicílio eleitoral nos dias de eleição. A medida contribui com um sufrágio mais amplo, embora, como se sabe, não totalmente universal.

Enquanto regra de decisão, o princípio da maioria, embora bastante incerto quanto à sua definição, parece, de maneira geral, obedecer ao critério democrático de que, quando há ampla participação em um processo decisional, a maioria deve decidir os rumos que serão tomados. O cuidado maior nem é definir o que é maioria e como esta maioria se forma, mas sim garantir meios de a maioria não desvirtuar completamente o poder e esmagar as minorias. Daí porque, em várias Constituições globais, algumas cláusulas essenciais somente podem ser alteradas ou pelo poder constituinte originário ou por um processo mais complexo de maioria qualificada.

Outra ilusão muito comum no processo democrático é a perquirição de um suposto bem público ou comum. Mas o termo é em si extremamente ambíguo e impreciso. No máximo, como ressalta Dallari (2003, p. 24), o termo nos remeterá para um "conjunto de condições, incluindo a ordem jurídica e a garantia de possibilidades que consintam e favoreçam o desenvolvimento integral da personalidade humana”. Não diz muito mais que a própria expressão bem comum.

Mais complexo ainda é distinguir aspectos procedimentais de aspectos substanciais para o alcance da finalidade pública, eis que quase sempre estas questões acabam se mesclando. Assim, por exemplo, após o forte apelo popular quanto à moralidade e a vida proba do candidato, a edição da Lei Complementar 135/2010 (Ficha Limpa), a despeito de seu forte aspecto substancial, acabou esbarrando em questões procedimentais no tocante à sua aplicação para as eleições de 2010, consoante decidiu o Supremo Tribunal Federal no julgamento do Recurso Extraordinário 633.703. Naquela ocasião, em face da regra 
procedimental do artigo 16 da Constituição Federal, o Ministro Luiz Fux ponderou que "por melhor que seja o direito, ele não pode se sobrepor à Constituição”.

Logo, é muito simplista a assertiva de que o caráter substancial da finalidade pública deve, em geral, se colocar acima das questões procedimentais. Nesse sentido, a contribuição de Dahl (2012, p. 277):

\begin{abstract}
Visto dessa forma, o processo democrático confere aos cidadãos um leque abrangente de direitos, liberdades e recursos suficientes para lhe permitir participar de maneira plena, como cidadãos iguais, da tomada de todas as decisões coletivas às quais estão obrigados. Se as pessoas adultas têm de participar das decisões coletivas para proteger seus interesses pessoais, inclusive seus interesses como membros de uma comunidade, para desenvolver suas capacidades humanas e para agir como seres autodeterminados e moralmente responsáveis, o processo democrático também é necessário para esses fins. Sob esse ângulo, o processo democrático não somente é essencial para um dos bens públicos mais importantes de todos - o direito das pessoas a se governar -, mas é, ele próprio, um rico pacote de bens substantivos.
\end{abstract}

Tampouco parece fácil definir quem é o povo que se autodetermina. Afirmar pura e simplesmente que se trata de um povo contido em determinado território, natural de determinado Estado ou que reside em um certo local não auxilia em questões mais complexas $^{11}$.

Esse é um problema que apenas pode ser parcialmente resolvido justamente pelos aspectos procedimentais acima descritos. Assim, embora os estrangeiros residentes no país tenham pleno interesse no desenvolvimento político do Estado brasileiro, a nossa Constituição, em seu artigo 14, optou por não possibilitar a eles o exercício do sufrágio. Da mesma forma, os menores de dezesseis anos, embora possam ter consciência política e pleno interesse, também foram excluídos de tal participação ativa.

A questão se torna mais dificultosa no tocante aos limites federativos, considerando a divisão entre União, Estado, Distrito Federal e Municípios, no sentido de delimitar a que tipo de interesse se atende com uma determinada participação ou conduta. Eis a razão pela qual nosso direito optou pela criação do chamado “domicílio eleitoral”, limitando em termos municipais a atuação do sufrágio do eleitor. Como o município é o menor ente federativo, inserido no Estado e na União, com o domicílio eleitoral, garante-se que o eleitor represente ao mesmo tempo seus interesses nos três níveis da federação.

\footnotetext{
11 “No mundo real, portanto, é muito mais provável que as respostas à questão do que constitui 'um povo' para fins democráticos venham da ação e do conflito político - os quais são, com frequência, acompanhados de violência e coerção - que de inferências racionais derivadas dos princípios e práticas democráticas. Haja vista que a teoria democrática não pode nos levar muito longe na solução desse problema em particular. As ideias democráticas, como afirmei, não produzem uma resposta definitiva. Elas pressupõem que uma resposta já foi, ou será, proporcionada pela história e pela política” (DAHL, 2012, p. 334).
} 
Não se olvide que existem interesses que podem estar delimitados por outros aspectos, como um determinado bairro de um município ou uma área que atinge dois Estados. Embora existam métodos alternativos de atendimento das controvérsias, como a cobrança pública de uma associação de bairro ou a cooperação interestadual, as soluções quase sempre se movem no sentido do ente que possa englobar todos os envolvidos, atento, evidentemente, às peculiaridades mais específicas.

É impossível resumir a existência de algumas instituições democráticas que sejam válidas para todos os Estados que assim se definam, ainda que tais Estados possuam um histórico desenvolvimentista bastante comum.

E ainda que elejamos determinados elementos - como a igualdade e a liberdade -, a definição de cada um deles acaba comprometendo a generalidade, remetendo-nos sempre a diferenciações específicas. Mas isso é típico da democracia. Extremamente danoso seria justamente o oposto: pretender delimitar todas as democracias com os mesmos elementos e com a mesma dureza típica de misturas químicas.

Dahl (2012, p. 379), a partir da análise de determinados dados, aponta, por exemplo, que determinadas condições que podem favorecer a poliarquia em um país, num dado momento, podem enfraquecê-la em outro, noutro momento. "Ou condições inicialmente frágeis podem fortalecer-se e assim favorecer a estabilidade de uma poliarquia já existente, como foi o caso na Alemanha Ocidental e no Japão nas décadas seguintes à Segunda Guerra Mundial”.

Mas, quiçá, o maior problema a envolver a democracia seja justamente definir, em determinados liames, a sua existência ou não. Como não é possível fazê-lo objetivamente, a única saída realista é a presença de indicadores democráticos.

O próprio professor de Yale retoma a ideia e apresenta, resumidamente, alguns desses indicadores (DAHL, 2012, p. 369):

1. As autoridades eleitas são investidas constitucionalmente do controle das decisões governamentais quanto às políticas públicas.

2. As autoridades eleitas são escolhidas, e pacificamente afastadas de seus cargos, em eleições frequentes, justas e livres, nas quais a coerção é bastante limitada.

3. Praticamente todos os adultos têm o direito de votar nessas eleições.

4. A maioria dos adultos também tem o direito de concorrer a cargos públicos abertos a candidatos em geral.

5. Os candidatos têm o direito, protegido por lei, à liberdade de expressão, particularmente a expressão política, incluindo a crítica às autoridades, à conduta do governo, ao sistema político, econômico e social estabelecido e à ideologia dominante.

6. Eles também têm acesso a fontes alternativas de informação que não sejam monopolizadas pelo governo ou por nenhum outro grupo em particular. 
7. Por fim, eles têm um direito efetivamente protegido por lei a formar associações autônomas e filiar-se a elas, inclusive associações políticas, como partidos políticos e grupos de interesse, que procuram influenciar o governo mediante a concepção eleitoral e outros meios pacíficos.

Nota-se, na concepção acima, que os elementos se apresentam não como definitivos, mas como generalistas, no sentido de esclarecer que a ausência de um deles ou uma qualificação um pouco diversa não significa necessariamente ausência de um regime democrático.

Assim, a democracia real, fora dos níveis do ideal, não apresenta nem uma única e nem respostas simples. Não apresenta medições matemáticas, mas conjecturas que podem ser classificadas como democráticas.

\section{SEMIÓTICA E SIMBOLOGIA DEMOCRÁTICA}

A democracia possui um significado em termos de simbologia. É quase um mártir, um desenho que se apresenta como salvador do Estado contemporâneo. Embora fugisse ao real motivo, muitos conflitos hodiernos se valeram da necessidade de instalação de um regime democrático em territórios alheios, como um símbolo que precisasse ser necessariamente considerado.

Com o intuito de encontrar armas de destruição em massa, em 2003, sob o comando do Presidente George W. Bush, os Estados Unidos promovem invasão ao território do Iraque. Um ano depois, todavia, Bush muda seu discurso e passa a dizer que a ocupação faz parte da promoção da Democracia e libertação de países em prol da paz mundial ${ }^{12}$.

Chega a parecer contraditório que a democracia possa ser implantada por um ente externo e mediante força. Em verdade, parecem ausentes aqueles elementos que apontamos como indicadores da democracia. Neste caso, sobretudo, a autodeterminação do povo iraquiano.

Muito antes, Kelsen (1993, p. 140) já ensinava:

O símbolo da democracia parece ter assumido um valor tão universalmente reconhecido que a substância da democracia não pode ser abandonada sem a manutenção do símbolo. É bem conhecida a afirmação sarcástica: se o fascismo fosse implantado nos Estados Unidos, seria chamado democracia. Consequentemente, o símbolo deve mudar seu significado de modo tão radical que possa ser usado para designar o extremo oposto: na teoria política soviética, a ditadura do partido comunista, pretendendo ser a ditadura do proletariado, é

\footnotetext{
${ }^{12}$ A propósito: <http://www.krysstal.com/democracy_whyusa_iraq03.html>. Acesso em 16 ago 2014.
} 
apresentada como democracia. É da maior importância desvendar o mecanismo conceptual através do qual foi possível chegar a essa distorção do símbolo.

O desenvolvimento semiótico, principalmente a partir do trabalho de Umberto Eco, e o estabelecimento de dados intermediários na relação entre remetente e destinatário, teve como mister explicitar elementos sígnicos que fazem parte da comunicação, mormente a orientação ideológica do trabalho, como acima visto.

As palavras são de Eco (2001, p. 245):

\begin{abstract}
ao discutir o exemplo de |ele segue Marx|, afirmávamos que a expressão envolvia também um nível de conotação 'ideológica' (seguir Marx é bom ou ruim?), capaz de determinar a desambiguação final da frase, conquanto esta não parecesse depender de alguma codificação registrável no âmbito da teoria dos códigos. Neste sentido, o fundo ideológico do destinatário, tão importante para todo o jogo de pressuposições referenciais e pragmáticas, parece consistir numa visão do mundo não completamente codificada e derivada do jogo processual da interpretação textual, das inferências, das menções, das pressuposições. Portanto, a ideologia apareceria (...) como um resíduo extra-semiótico capaz de determinar a semiose, agente como catalizador nos processos abdutivos, mas estranho à codificação.
\end{abstract}

Mas assim como o trabalho sígnico atua fortemente como crítica social, possui a vertente de também esconder o elemento ideologizador da mensagem. Isto é, valer-se de um determinado símbolo como verdadeiro elemento da mensagem, enquanto, na realidade, este símbolo cumpre o papel de iludir a comunicação, desvirtuando a mensagem para um lado supostamente mais benéfico.

É como vimos acima no tocante ao papel exercido pela própria democracia no Estado Comunista. Este Estado, como sabemos, estava bem longe de se apresentar de fato democrático. Mas valia-se deste ídolo para vangloriar o comunismo enquanto salvação democrática. Melhor dizendo, escondia o verdadeiro sentido do Estado Comunista pelo símbolo da democracia ${ }^{13}$.

Como reconhece a relação entre semiótica e Direito, a presença dos símbolos é inerente ao jurídico enquanto linguagem cultural. O professor Tércio Sampaio Ferraz Junior (1997, p. 171) ensina que o Direito não é “nem a positivação nem o conjunto das normas positivadas, mas o próprio homem que, do interior da positividade que o cerca, representa-se o sentido das normas que ele estabelece”.

Em mesmo sentido, ensina a professora Maria Francisca Carneiro (2013, p. 85):

\footnotetext{
13 “Quando um código associa os elementos de um sistema veiculante aos elementos de um sistema veiculado, o primeiro se torna a expressão do segundo, o qual, por seu turno, torna-se o conteúdo do primeiro. Há função sígnica quando uma expressão se correlaciona a um conteúdo, tornando-se ambos os elementos correlatos funtivos da correlação" (ECO, 2001, p.39).
} 
Preferimos pensar que existem diversas “linguagens” no interior do Direito, por ele produzidas. Como em todas as linguagens, o elemento ideológico permeia e atravessa o discurso jurídico, talvez de forma mais intensa do que em outras formas linguísticas, conferindo-lhe um alto grau de elaboração.

Mas como o discurso sempre se conduz pelos interesses em jogo, o desvio acaba servindo a um reposicionamento ideológico, principalmente no caso da democracia vista enquanto um ídolo, o que torna sedutora sua utilização enquanto sinal de um determinado regime, ainda que este regime esteja muito longe do perfil democrático.

A atribuição de democrático ao regime comunista, como exemplificado, tem relação com a ideia de ditadura do proletariado extraída dos escritos de Marx. Já vimos, pois, a partir dos estudos kelsenianos, que para os comunistas apenas este regime poderia ser indicativo do perfil democrático. A prática, todavia, demonstrou que a democracia atingiu objetivos mais nobres justamente aliada ao capitalismo.

Assim, o símbolo democrático pode ser utilizado para fazer crer enquanto tal regimes completamente diversos a ele. O trabalho midiático nessa seara, ainda mais quando a mídia ou é exclusivamente pública ou controlada pelo governo, é essencial para vangloriar o símbolo e conectá-lo ao regime dominante. A falta da espontaneidade midiática, o que, em último grau, se atrela à própria liberdade, pode conduzir a objetivos espúrios, negligenciadores da realidade ${ }^{14}$.

Daí porque a investigação dos sinais pela tradução semiótica e a conexão midiática, embora revolucionária, é essencial para compreender o real significado que se escora por trás de uma mensagem de cunho supostamente democrático (CARNEIRO, 2013, p. 154). Nessa razão, parece pouco crível que, do lado oposto, a “caça aos comunistas”, no sentido de preservar o Estado Democrático, tenha em si qualquer real ligação com a democracia, já que claramente antipluralista e que serviu a justificar dois golpes de Estado no Brasil - o de 1937 por Getúlio Vargas após a farsa do Plano Cohen e o de 1964 pelos militares.

Tal a importância do estudo dos símbolos democráticos, de forma que a grife democracia não sirva como parte no autoengano da população acerca da real existência desse regime.

\footnotetext{
14 "Entretanto, as situações da mídia nem sempre são espontâneas, mas obedecem a uma programação prévia, salvo raras exceções, como por exemplo, os 'reality-shows'. Ora, essa falta de espontaneidade influencia de algum modo o desenvolvimento da percepção social da mídia sobre o Direito e, em consequência, influencia também a chamada ‘consciência legal’ por parte da população” (CARNEIRO, 2013, p.149-150).
} 
Como não há uma única democracia, muito menos haverá um único modelo democrático que possa ser auto-utilizado por qualquer Estado, independentemente das condições em que se ergueu a suposta democracia.

\title{
5. VIVÊNCIA DEMOCRÁTICA
}

A sensação de viver a democracia é o melhor indicador da existência de um regime fielmente democrático.

Rodrigo Cadore (2011, p. 40), em excelente trabalho apresentado junto à Faculdade de Direito da Universidade de São Paulo, analisa a relação dinâmica do Direito, conferindolhe "vida":

\begin{abstract}
Direito é, afinal, uma expressão de vida, um modo específico de viver. É, nessas linhas, uma vivência, que se engendra processualmente, num continuum. Um modo de agir (e de discursar) associado à "resolução de conflitos", de desacertos surgidos na coexistência humana em grupo. Os adjetivos derivados de jus/ius apostos ao substantivo vivência vêm apenas a qualificar a especificidade ritual/processual de determinadas manifestações de vida humana que não obstante a variabilidade e heterogeneidade seguem designáveis por direito.
\end{abstract}

A vivência jurídica pode acabar encontrando respostas diversas e opostas num mesmo sistema, ante o engodo de um sistema que encontre respostas prontas e acabadas na legislação. "Não há autoridade humana que possa prever, mediante exaração de disposições pretensamente normativas, toda a complexidade e variabilidade na vivência social” (CADORE, 2011, p. 262).

Em seu trabalho, Cadore relembra um fato marcante ocorrido nas eleições de 2010.

Havia uma discussão acerca da interpretação do artigo 16-A da Lei 9.504/97¹5, em conjunto com o artigo 175 do Código Eleitoral ${ }^{16}$, acerca da computabilidade dos votos dos candidatos que tiveram o registro indeferido pela Justiça Eleitoral.

\footnotetext{
15 Art. 16-A. O candidato cujo registro esteja sub judice poderá efetuar todos os atos relativos à campanha eleitoral, inclusive utilizar o horário eleitoral gratuito no rádio e na televisão e ter seu nome mantido na urna eletrônica enquanto estiver sob essa condição, ficando a validade dos votos a ele atribuídos condicionada ao deferimento de seu registro por instância superior. Parágrafo único. O cômputo, para o respectivo partido ou coligação, dos votos atribuídos ao candidato cujo registro esteja sub judice no dia da eleição fica condicionado ao deferimento do registro do candidato.

${ }^{16}$ §2 ${ }^{\mathbf{0}}$ Serão nulos os votos, em cada eleição pelo sistema proporcional: I - quando o candidato não fôr indicado, através do nome ou do número, com clareza suficiente para distinguí-lo de outro candidato ao mesmo cargo, mas de outro partido, e o eleitor não indicar a legenda; II - se o eleitor escrever o nome de mais de um candidato ao mesmo cargo, pertencentes a partidos diversos, ou, indicando apenas os números, o fizer também de candidatos de partidos diferentes; III - se o eleitor, não manifestando preferência por candidato, ou o fazendo de modo que não se possa identificar o de sua preferência, escrever duas ou mais legendas diferentes no espaço relativo à
} 
O Tribunal Superior Eleitoral, no julgamento do Mandado de Segurança 403.463, em placar apertado (4x3), vencido o Ministro Marco Aurélio, entendeu que os votos dos inelegíveis era simplesmente perdido. Para o citado Ministro, todavia, os votos deveriam ser computados para a legenda, eis que a “organicidade do Direito (,,,) consagrou, sob o ângulo da definição dos votos - que, necessariamente, antecede o início da legislatura - e considerada a nulidade, a separação entre a legenda e o candidato”. Por conta disso, a nulidade constante do artigo 175, parágrafo único, do Código Eleitoral fulminava a eleição do candidato, mas não afastava o entendimento de os votos fossem computados para a legenda, já que ao digitar o número do candidato, os dois primeiros são reservados a esta.

Todavia, o TSE insistiu na tese de que o artigo 16-A da Lei 9.504/97 pretendeu atribuir maior responsabilidade aos partidos na escolha de seus candidatos. Conforme ressaltou o Ministro Arnaldo Versiani, o artigo pretendia precaver o sistema dos "chamados candidatos puxadores de votos, que posteriormente podem ser declarados inelegíveis, mas que beneficiam as legendas com a quantidade de votos que recebem”.

Mesmo assim, o Ministro Marco Aurélio continuou concedendo liminares em Mandados de Segurança para que os votos fossem computados aos partidos, o que ocorreu nos Estados do Ceará, Mato Grosso, Santa Catarina, São Paulo, Rio de Janeiro e Rondônia. Nos demais estados, seguindo o julgamento do TSE, os votos vinham se considerados nulos.

A questão trazia em si “efeitos também distintos (,,,) interferindo na composição das bancadas do Congresso e das Assembleias Legislativas Estaduais”, cuja sorte vinha sendo determinada, grosso modo, pela "loteria da distribuição processual” (CADORE, 2011, p. 260).

A democracia, assim, se viu discutida pelo mesmo Tribunal, com decisões completamente divergentes e com interferências entre si, a partir da interpretação conferida pelos seus julgadores, rasgando qualquer ideia de que no Direito - e no caso específico, a democracia - possui a chave de traduzir respostas simples e lógicas para os mesmos problemas (CADORE, 2011, p. 259-262).

Por isso a democracia é vivência, talqualmente o direito. Longe da interferência do Judiciário no processo eleitoral, seus elementos só podem ser consubstanciados na prática. Não é possível medir com a mesma intensidade os graus democráticos em rincões que $\$ 3^{\circ}$ Serão nulos, para todos os efeitos, os votos dados a candidatos inelegíveis ou não registrados. $\$ 4^{\mathbf{0}} \mathrm{O}$ disposto no parágrafo anterior não se aplica quando a decisão de inelegibilidade ou de cancelamento de registro for proferida após a realização da eleição a que concorreu o candidato alcançado pela sentença, caso em que os votos serão contados para o partido pelo qual tiver sido feito o seu registro. 
protagonizaram os votos de cabresto e o fenômeno do coronelismo e os grandes centros que ficaram de certa forma imunes a essas ocorrências. Aliás, parece tão óbvio que a cultura eleitoral seja tão diversa ao longo dos 5.570 municípios brasileiros, com populações entre oitocentos e onze milhões de habitantes, na circunscrição do quinto maior país, territorialmente falando, do mundo ${ }^{17}$.

Dessas realistas lições, é razoável o questionamento de Manoel Gonçalves Ferreira Filho (2011, p. 30): “quererá o povo governar-se?”.

A questão funda-se não apenas no fato de que o poder de fato é exercido por uma minoria politicamente vinculada, mas, principalmente, diante da percepção de que uma grande parte da população é desinteressada politicamente, o que, não se negue, fala não apenas pela história brasileira, mas, atualmente, pela descrença generalizada na classe política.

Há uma frase anônima, bastante difundida, que apresenta os seguintes dizeres: "Eu tenho um amigo que se recusa a votar. Ele insiste que não importa em quem você vote, sempre ganha um político”.

E esse não parece ser um fenômeno brasileiro.

Manoel Gonçalves Ferreira Filho (2011, p. 30) aponta que nos Estados Unidos a maioria da população sequer se dá ao trabalho de votar - lembrando que o voto é facultativo -, muito menos acompanhar a evolução da política.

Apenas em 2008, com a primeira eleição de Barack Obama, como noticiou o Zero Hora, é que se assistiu uma intensidade de participação tão alta nos Estados Unidos desde 1908. Cerca de 136 milhões de eleitores foram às urnas, representando um percentual de 64,1, ultrapassando até mesmo o embate entre John F. Kennedy e Richard Nixon em $1960^{18}$.

Como nunca, o povo norte-americano viu-se novamente convocado para participar das decisões acerca dos novos rumos do país, o que comprova que a vivência democrática tem o condão de se reprogramar para atrair o interesse da população, mormente em momentos de desconforto, como os últimos anos do governo de Bush filho ${ }^{19}$.

No Brasil, a insatisfação ganhou as ruas em 2013, com a gota de água a romper a tensão do líquido acerca do preço do transporte público. Na prática, inúmeras foram as

\footnotetext{
${ }^{17}$ Dados: <http://www.cidades.ibge.gov.br/> e <http://www.brasil.gov.br>. Acesso: 17 ago 2014.

18 Disponível em: <http://zh.clicrbs.com.br/rs/noticia/2008/11/eleicao-nos-eua-tem-maior-participacao-emdecadas-dizem-analistas-2282672.html>. Acesso: 17 ago 2014.

19 "Lembrem-se os principais. De modo geral, um terço do eleitorado não vota nas eleições presidenciais, dois terços apenas toma conhecimento das questões políticas pelo que vê ou ouve dos keios de comunicação de massa, jamais se dando a pena de recolher qualquer outra informação sobre os temas em debate, ou os candidatos em disputa. Nota-se dos que leem jornais, $47 \%$ não leem, quanto à política, mais que as manchetes” (FERREIRA FILHO, 2011, p.30-31).
} 
questões levantadas, nas mais diversas searas públicas, em um movimento de afronta geral à classe política dominante. Mas apenas o resultado das eleições de 2014 poderão comprovar se o povo brasileiro realmente tornou-se mais inserto na política pública ou se o movimento quedou-se frio.

O diagnóstico de Bruce Ackerman (2006, p. 426) é bastante elucidativo:

\begin{abstract}
É uma pena que grande parte da moderna teoria da democracia tenha desviado a nossa atenção dessa questão. As fontes dessa distração são muitas e variadas. Por um lado, a cidadania comum encontra-se diante de uma constante ameaça proveniente daqueles intelectuais radicais que balançam a cabeça com desdém perante ao nível geral de apatia e ignorância, de egoísmo e mediocridade prevalecentes entre os cidadãos em geral. Do seu elevado pedestal, a escassez sem remorsos da virtude civil faz com que o envolvimento estadunidense no governo autônomo pareça superficial e patético. Seria melhor manter esse envolvimento no nível de simbologia pura e consolidar a autoridade de uma elite intelectual que saiba como governar eficientemente. Ou, talvez, a atitude correta da elite seja lavar as suas mãos da política democrática e se recolher às universidades para contemplar a sua própria sabedoria.
\end{abstract}

Muito dessa descrença acerca da elite intelectual tem relação com todas as divagações acerca da democracia em nível ideal e as malsinadas tentativas de apresentar modelos fechados e simples da edificação democrática.

Mas Ackerman (2006, p. 428) aponta ainda a ausência da participação pluralista, mormente das minorias que possuem os interesses mais suprimidos, como responsável pela descrença. "Como o número e a diversidade desses grupos enfraquecidos se tornou aparente, o pluralismo estadunidense começo a demonstrar a sua nocividade”.

Daí porque a busca da inserção desses grupos torna-se a missão precípua no anseio de remediar essa sangria democrática, ainda que esteja longe de atingir qualquer nível de pluralismo ideal. Mas ao menos convocou os atores políticos - com destaque para o Judiciário - a voltarem-se com mais atenção aos problemas da falta de participação. Esse é um problema que apenas a vivência democrática, próxima à realidade cotidiana, pode oferecer respostas mais ou menos úteis.

E se a população atenderá ao seu próprio pleito de participar ativa e praticamente, é uma resposta que o tempo dará à vivência.

\title{
6. CONCLUSÃO: A RELEITURA SEM MODELOS
}

Quais, então, os rumos para a democracia nesse novo contexto que, alterando a compreensão intelectual, verte-se em benefícios práticos? 
A constatação dos problemas e das questões que são inerentes a um regime instável, como identifica Dallari (2003, p.303), levaram a uma crise do Estado Democrático e à percepção óbvia de que a democracia não é um ideal.

De uma forma mais ampla, o supracitado professor franciscano analisa (DALLARI, 2003, p. 303):

Tudo isso gerou a crise do Estado Democrático, levando os mais pessimistas à conclusão de que a democracia é utópica, porque na prática encontra obstáculos intransponíveis, emaranhando-se em conflitos insuperáveis. O povo, julgado incapaz de uma participação consciente, deveria ser afastado das decisões, ficando estas a cargo de indivíduos mais preparados, capazes de escolher racionalmente o que mais convém ao povo. A liberdade considerada um mal, porque é fonte de abusos, devendo portanto ser restringida, a bem da ordem e da paz social. A igualdade, por sua vez, não poderia ser aceita, pois os governantes, que sabem mais do que o povo e trabalham para ele, devem gozar de todos os privilégios, como reconhecimento por seus méritos e sua dedicação. Quanto à organização do Estado e do governo, é preciso que exista uma forma rígida, para que se assegure o máximo de eficácia do Estado.

Mas, em continuidade, ressalta que aceitar tais argumentos seria uma rejeição da própria democracia, e a aceitação de um regime autocrático. Afastando o pessimismo inerente àqueles que criticam o Estado Democrático, ressalta que a melhor das ditaduras causa muito mais prejuízos do que a pior das democracias. O problema, como aduz, é, principalmente, a “inadequação das concepções” (DALLARI, 2003, p. 303).

Assevera que o ideal democrático seria possível de ser atingido se "seus valores e sua organização” fossem “concebidos adequadamente”. Apresenta alguns pressupostos para tanto: eliminação da rigidez formal, supremacia da vontade do povo, a preservação da liberdade e a preservação da igualdade (DALLARI, 2003, p.304-307).

Com todo o respeito que é devido ao mestre franciscano, assim não pensamos. A apresentação de novas concepções, mormente a partir das leituras das anotações do supracitado professor, acaba afastando a democracia do nível ideal, tantas vezes ressaltado. Em verdade, acaba comprovando nossa teoria sobre sua inexistência, diante até da impossibilidade de se compreender o que seria uma democracia ideal.

Mas, então, o próprio professor, depois de apresentar sua concepção conclui:

Aí estão os pressupostos fundamentais do Estado Democrático possível. Dotando-se o Estado de uma organização flexível, que assegure a permanente supremacia da vontade popular, buscando-se a preservação da igualdade de possibilidades, com liberdade, a democracia deixa de ser um ideal para se converter na expressão concreta de uma ordem social justa (DALLARI, 2003, p. 306-307). 
As discussões do entorno democrático, a bem da verdade, acabam absorvidas em prol de um bem maior. A análise elementar serve à compreensão da democracia como um todo, não apenas do entendimento do próprio elemento. Por isso, não é possível afirmar com segurança que uma baixa participação popular necessariamente conduz a um quadro democrático. Os Estados Unidos se apresentam sob matiz democrática, e diante dos elementos democráticos não há dúvida de tal constatação. Mas seria o voto indireto democrático? A resposta depende de uma análise conjuntural. Classificar o conjunto por antidemocrático por conta de questões inerentes a um único elemento seria muito simplista para um problema tão complexo como a democracia.

Assim, por exemplo, há muita discussão acerca do conflito entre o valor liberdade e o voto obrigatório, entre nós. Nos termos da nossa Constituição, consoante artigo $14, \S 1^{\circ}$, I, o voto é obrigatório para os maiores de dezoito anos e, conforme inciso II, é facultativo para os analfabetos, maiores de setenta anos e maiores de dezesseis e menores de dezoito anos. E, como lembra Peña de Moraes (2013, p. 620), o alistamento também é obrigatório "no prazo de um ano da obtenção da nacionalidade brasileira”.

Afinal, seria o sufrágio um direito ou um dever? Se visto sob o primeiro prisma, pareceria contraditório que fosse obrigatório. Analisado sob o segundo, haveria ofensa à liberdade, elemento base da democracia.

Pensamos, todavia, que a situação se justifica justamente por uma necessidade de maior inserção política da sociedade em uma democracia considerada recente como a nossa. O valor da participação política não deve apenas ser possibilitado pelo Estado, mas também incentivado. A definição do voto como obrigatório neste momento é salutar para o aperfeiçoamento da democracia brasileira. Portanto, considerando nosso Estado Democrático, não pode ser visto como uma afronta à própria democracia.

A democracia, como dissemos, tem não apenas a missão, mas a característica de, num regime em que prepondere a liberdade, se redesenhar.

Mas, partindo de Dahl, não apenas a participação tem importante papel nesse mister. Também a oposição política cumpre papel preponderante na engenharia democrática. E, igualmente, acaba se redesenhando conforme as características do regime democrático.

Instrumento essencial na democracia brasileira para proporcionar a oposição das minorias políticas é a possibilidade da instauração de Comissões investigatórias por um terço da Câmara ou do Senado ${ }^{20}$. Recentemente, deparamo-nos até com a instalação de duas

\footnotetext{
20 “A criação das comissões parlamentares de inquérito se dá mediante requerimento subscrito pelo menos por
} um terço dos membros de qualquer das Câmaras do congresso, ou de ambas, em conjunto, como está prescrito 
Comissões para investir o mesmo objetivo: uma do Senado e uma Mista ${ }^{21}$. E após denúncias de “jogo de carta marcada”, iniciaram-se procedimentos para investigar a própria Comissão Parlamentar de Inquérito do Senado Federal, deixando patente a função que as comissões prestam às minorias políticas.

A oposição no cerne democrático passa a exigir, no natural jogo de forças, o fair play quase como uma obrigação moral. A propósito, após a morte do candidato Eduardo Campos, em acidente aéreo no dia 13 de agosto de 2014, como amplamente noticiado, inclusive no exterior, os outros dois candidatos principais, a Presidente Dilma Rousseff e o Senador Aécio Neves, suspenderam suas campanhas até 19 de agosto, quando se iniciaram as propagandas eleitorais ${ }^{22}$.

Assim, a democracia fora de um rumo idealista se constrói paulatinamente. Ainda durante o governo militar, Manoel Gonçalves Ferreira Filho (1974, p. 27) escreveu as seguintes palavras:

\begin{abstract}
A democracia que é possível na realidade consiste no governo por uma minoria democrática, ou seja, por uma elite formada conforme a tendência democrática, renovada de acordo com o princípio democrático, imbuída do espírito democrático, voltada para o interesse popular: o bem comum.
\end{abstract}

Diante de tudo que já expomos ao longo deste trabalho, tais apreciações parecem sempre nos remeter para outras questões igualmente insolúveis. Mas Manoel Gonçalves teve o mérito de perceber que a democracia depende em grande parte de si mesma, num eterno jogo de reprodução e reconstrução. Reprodução quando os elementos parecem atender com satisfação o espírito democrático de um povo. Reconstrução, quando não.

Não se diga que foram fracassadas as tentativas democráticas nos percalços brasileiros, mormente entre os anos de 1964 e 1985. Nem que o Brasil ainda não atingiu uma democracia plena, pois isso jamais irá ocorrer, não apenas aqui, mas em qualquer lugar do mundo, ante a ausência de qualquer condição que comprove que determinado projeto democrático seja pleno.

no artigo 58, $\S 3^{\circ}$, da Carta Magna em vigor. Basta o cumprimento deste requisito, além é obvio, da indicação de fato determinado, e a comissão será automaticamente criada, para funcionar por prazo certo. Ao comentar o preceito similar, da Constituição de 1967, Pontes de Miranda enfatiza com propriedade que 'há o dever de criar a comissão de inquérito, porque o art. 37 foi explicito em estatuir que se há de criar (verbo 'criação'), desde que o requeira um terço ou mais dos membros da câmara ou das câmaras'. Na espécie, o direito da minoria parlamentar (um terço), por este mesmo aspecto, exige norma expressa na Constituição, e daí, o acerto dos Constituintes, ao introduzi-la no texto maior" (SALGADO, 2001, p. 53).

${ }^{21}$ As citadas CPIs tiveram como intento a investigação sobre a compra da Refinaria de Pasadena e a construção da Refinaria Abreu e Lima, ambas da Petrobras.

${ }^{22}$ Notícia do site da Rede Alemã DeutschWelle. Disponível em: <http://dw.de/p/1CuPk>. Acesso: 18 ago 2014. 
A democracia é um fruto detalhado da análise das instituições e de como seus elementos têm sido tratados nos quatro cantos do Brasil cotidianamente. O primeiro passo para uma mudança no modus operandi em relação à sua contínua efetivação é compreender a inexistência de qualquer modelo que possa nos guiar, a não ser a nossa própria vontade democrática.

A democracia é esta que vivenciamos, que urge das ruas, das manifestações contrárias ou favoráveis à classe política, do exercício de sufrágio e que nele não se esgota.

O problema maior das pompas com que a democracia foi tratada até então é justamente o fato de que esse discurso esconde seus verdadeiros caracteres. Elevar a democracia aos céus, homenageá-la, conferir-lhe o título de governo dos deuses, tudo isso nada serve à compreensão do processo democrático na prática. No máximo, faz a elucubração de um conceito que sequer existe no campo intelectual-material.

Como insistentemente bradava Voltaire sobre os discursos acadêmicos, esses elogios acabaram se tornando "uma espécie de lei para entediar o público”23

\section{BIBLIOGRAFIA}

ACKERMAN, Bruce. Nós, o povo soberano: fundamentos do direito constitucional. Belo Horizonte: Del Rey, 2006.

BORGES DE OLIVEIRA, Emerson Ademir. Ativismo judicial e o papel das Cortes Constitucionais nas correções de rota da crise da democracia representativa. Revista de Direito Público. Porto Alegre, n. 40, p. 25-49, 2011.

. O impacto do controle de constitucionalidade na evolução da democracia. 164f. Dissertação (Mestrado em Direito do Estado) - Faculdade de Direito, USP, São Paulo, 2013.

CADORE, Rodrigo Garcia. Vivência jurídica. 300f. Dissertação (Mestrado em Filosofia do Direito) - Faculdade de Direito, USP, São Paulo, 2011.

CARNEIRO, Maria Francisca. Teoria jurídica contemporânea: semiótica, proporções e filosofia do direito. Rio de Janeiro: LumenJuris, 2013.

DAHL, Robert A. A democracia e seus críticos. São Paulo: Editora WMF Martins Fontes, 2012.

. How democratic is the American Constitution? New Haven/London: Yale University Press, 2001.

${ }^{23}$ VOLTAIRE. Cartas filosóficas. p.135. 
. Poliarquia: participação e oposição. São Paulo: Edusp, s.d.

DALLARI, Dalmo de Abreu. Elementos de Teoria Geral do Estado. 24.ed. São Paulo: Saraiva, 2003.

ECO, Umberto. Tratado geral de semiótica. 2.ed. São Paulo: Perspectiva, 2001.

FERRAZ JÚNIOR, Tércio Sampaio. Direito, retórica e comunicação: subsídios para uma pragmática do discurso jurídico. 2.ed. São Paulo: Saraiva, 1997.

FERREIRA FILHO, Manoel Gonçalves. A democracia no limiar do século XXI. São Paulo: Saraiva, 2001.

. A democracia possível. 2.ed. São Paulo: Saraiva, 1974.

KELSEN, Hans. A democracia. São Paulo: Martins Fontes, 1993.

LEAL, Victor Nunes. Coronelismo, enxada e voto: o município e o sistema representativo no Brasil. 7.ed. São Paulo: Companhia das Letras, 2012.

MORAES, Guilherme Peña. Curso de direito constitucional. 5.ed. São Paulo: Atlas, 2013.

NIETZSCHE, Friedrich. Ecce homo. 2.ed. São Paulo: Escala, s.d.

SALGADO, Plínio. Comissões Parlamentares de Inquérito: CPI: doutrina, jurisprudência e legislação. Belo Horizonte: Del Rey, 2001.

SCHMITT, Carl. Legalidad y legitimidad. Madrid: Aguilar, 1971.

SCHUMPETER, Joseph A. Capitalism, socialism and democracy. 2.ed. New York and London: Harper \& Brothers Publishers, 1947.

VOLTAIRE. Cartas filosóficas. São Paulo: Escala, s.d. 